\title{
Improving Competitiveness in the Member States of the Eurasian Economic Union: A Blueprint for the Next Decade
}

\author{
Christopher A. Hartwell \\ Department of International Management \\ Kozminski University \\ ul. Jagiellonska 57-59, 03-301 Warsaw, POLAND \\ M: +48 538175826 \\ chartwell@kozminski.edu.pl; Christopher.hartwell@case-research.eu
}

\begin{abstract}
The Eurasian Economic Union (EAEU) has made incredible strides in becoming an integrated body over the past ten years, just as the European Union appears to be coming apart. But while the EAEU may be going against overall global trends of integration, it is becoming part of a broader global process of economic regionalism that is shaping competitiveness. This paper applies a SWOT analysis to current and projected EAEU member states, and identifies where the difficulties and opportunities for the EAEU's member countries will be in improving competitiveness in the coming years. Will increased regionalism or even micro-competitiveness be improved for the member states through the process of broader or deeper Eurasian integration? The key conclusions are that the EAEU's own institutional arrangements may foster competitiveness if it is able to remove some of the barriers to innovation that currently exist in the bloc's member states, in particular Russia.
\end{abstract}




\section{Introduction}

The Eurasian Economic Union (EAEU), comprised of Russia, Belarus, Kazakhstan, and newest member Armenia (with Tajikistan and Kyrgyzstan waiting closely in line), has made incredible strides in becoming an integrated body over the past ten years. While talk of a closer economic space amongst the former Soviet republics has been ongoing since literally the moment the Soviet Union collapsed, the EAEU's progress has accelerated since the global financial crisis. Proceeding from a loose Commonwealth (the CIS) to a customs union and a planned Single Economic Space (SES) for the three core states in just five years, the EAEU has accomplished in a short period of time a process that took the European Union decades.

As remarked elsewhere (Hartwell 2013), however, the EAEU's journey has been complicated by a lack of understanding regarding its end game. The inherent contradiction between deeper integration, with its focus on removal of barriers and harmonization of legal and administrative forms within the bloc, and broader integration, which seeks to bring as many new members into the bloc as possible, has been especially glaring over the period of 2012-2015. Indeed, given recent geopolitical events, first and foremost Russia's invasion of Ukraine, the balance has shifted towards enlargement and away from deeper integration. Moreover, while the EAEU has made some excellent strides in lowering trade and investment barriers within the bloc, it appears that these liberalization gains have come at the expense of those outside the union, with the Russian tariff imposed as the common external tariff rate. This more than doubled the rate of a country like Kazakhstan (Tarr 2012), which was relatively liberal in its dealings with the outside world.

A further irony, and one that is the explicit focus of this paper, is that the Eurasian Economic Union has undertaken its journey of broad-based economic integration just as the rest of world is become more fragmented; the lingering Eurozone crisis and the EU's policy towards Ukraine has exposed rifts amongst European Union members, while currency movements in the developed world have made macroeconomic coordination more distant. Indeed, the postglobal financial crisis world has shown that global growth challenges have become more pronounced, exacerbated by poor policy choices in the developed countries that have made stagnation appear to be the "new normal" (Summers 2013). Whereas a prime reason for broader integration in earlier years may have been to improve a country's competitiveness (via access to markets, increased trade, and technology transfer), the events of the past decade have shown the dark side of integration.

But while the EAEU may be going against overall trends in global economic fragmentation, it may simultaneously be part of another movement, the shift towards economic regionalism for driving economic growth and, especially, in shaping competitiveness. With the failure of broader-based and multilateral economic initiatives over the past decade, as typified by the World Trade Organization's Doha round and the inability of countries to agree on any new broad trade liberalization (Bouet and Laborde 2010), countries have begun to look closer to home for trade agreements and drivers of competitiveness. In Asia especially, regional initiatives have taken the place of global trade fora, pushing for preferential treatment within the region, shaping new institutions, and coordinating macroeconomic policies for crisis prevention and management (Campanelli and Kawai 2014). In this sense, the EAEU is part of a broader trend towards smaller-scale integration in lieu of global liberalization. 
In addition to the possible trade gains of localized liberalization, these regional initiatives have been seen as a crucial way to bolster country-level competitiveness, "enhanc[ing] productivity and international competitiveness through exploitation of scale economies and dynamic efficiency" (Dee 2007:406). As noted already, economic integration may indeed help a country's overall and sectoral competitiveness via increased market access (Krugman and Venables 1990), increased flows of FDI (Motta and Norman 1996), factor mobility (Jovanovic 2006), and increased specialization (Landesmann and Stehrer 2006). Industry may also be more supportive of liberalization on a regional (rather than multilateral) basis, for, as Mansfield and Milner (1999) conjecture, industries characterized by economies of scale can increase this scale through regional integration while also benefiting from a more tailored protectionist regime; thus, a regional trade agreement that allows for internal expansion but with some constraints placed on the outside world can bolster the competitiveness of existing exporters. In a similar vein, the European Union was predicted to create a competitive disadvantage for non-EU firms due to the ease of intra-EU trade, thus spurring on countries from other trading blocs (notable the European Free Trade Area, or EFTA) to join the EU outright to avoid this issue (Baldwin 2005). Knobel and Pereboyev (2013) predict similar effects can occur in Armenia, Moldova, and Tajikistan if they were to join the EAEU and avoid the same deleterious consequences seen by the EFTA members upon completion of the EU's internal market.

However, the success of economic regionalism in promoting competitiveness has not yet been proven, nor is there any clear indication of its effects over the past seven years; it is difficult to disentangle purely regional effects, as they often occur as part of a package of reforms (Milner 1999, Topalova and Khandelwal 2011). Moreover, while there is no doubt that increased knowledge sharing and economies of scale can assist exporters, if coupled with a "fortress" approach to outside the region (as conjectured by Mansfield and Milner 1999 and proven in Motta and Norman 1996) it is difficult to see if the economies of scale outweigh the deadweight losses imposed by protectionism.

Beyond these methodological issues, a more basic conceptual issue has also reared its head, in that the regionalism debate still focuses on competitiveness almost exclusively at the countrylevel. Competitiveness is increasingly migrating away from being delineated solely by country borders, gaining importance locally and in specific geographic regions that may disregard national boundaries (Hanson 2001, Johnson 2009). Given these sub-national realities, could even the scaling-down of liberalization ambitions from multilateral to regional be too highly aggregated to improve competitiveness for a country writ large? That is, even by scaling back integration ambitions to a small set of countries (as in the EAEU), can the supposed improvements in competitiveness materialize? Or does the focus need to be at a smaller geographic level?

The purpose of this paper is to understand how a regional organization such as the EAEU can help or hinder the process of improving its member countries' competitiveness, either at the country-level or at smaller geographic units. In the context of a changing world, with economic regionalization on the increase, selective globalization and sub-optimal growth paths becoming normal, and increasing use of trade as a weapon, is an economic alliance such as the EAEU necessary for improving the competitiveness of its member states? Using a strengths, weakness, opportunities, and threats (SWOT) analysis, and drawing on the literature regarding the competitiveness-enhancing effects of trade blocs, I examine the competitiveness challenges in the EAEU member countries and where the EAEU can help its member states' economies to compete globally. The results of this analysis show that the EAEU may have a role to play in 
helping its members, generally laggards on the world stage in terms of competitiveness, to increase their productivity via free movement of factors. More importantly, the EAEU may provide some institutional incentives to allow for liberalization which then in turn will lead to gains in competitiveness, incentives that have been absent thus far. Such an outcome will be dependent upon political will, but for this I am less optimistic.

\section{Defining “Competitiveness" Downward}

In order to understand the effect of regional trading blocs such as the EAEU on the competitiveness of its members, it is instructive to take a step back and understand what is meant when we speak of "competitiveness" in general. As an early review of the concept showed, the idea of "competitiveness" depends upon who is saying it, what discipline they are coming from, whether or not it is a private or public sector person who is discussing it, and whether or not the concept is applied at the national or the firm level (Waheeduzzaman and Ryans 1996). Indeed, traditional conceptions of competitiveness began with the idea of the firm and how it competes in its environment, with Duren et. al (1994:37) offering a definition of competitiveness as "the sustained ability to profitably gain and maintain market share." The sources of this competitiveness are still debatable, however, providing the inputs for several thousand scholarly journal articles and public debates. Man et al. (2002), among others, posit that managerial acumen and abilities are key for developing firm competitiveness, especially at the small and medium enterprise (SME) level, while Mesquita et. al (2007) show how intraindustry associations in Brazil helped to influence the competitiveness of car manufacturers, and Wan et. al (2005) show that decentralized structures, a belief in innovation, and a willingness to take risks and exchange ideas have been the reasons for competitive success in Singapore.

The extension of the idea of competitiveness to the national level comes of course from the work of Michael Porter (1990:73), who succinctly stated that "a nation's competitiveness depends on the capacity of its industry to innovate and upgrade." This definition has been refined since his early work, leading to some methodological confusion, as competitiveness has come to encompass simple productivity or output per worker (Ketels 2006), effective public policies (Duren et. al 1994), the creation of an environment where innovation can flourish (Kao et. al 2008), cost conditions related exchange rate movements (Thompson 2004), or simply the ability to provide prosperity (Snieška and Drakšaitè 2007) or "welfare" (Aiginger 2006). Moreover, there is somewhat confusion in the literature between the benefits of competitiveness and what drives it, as shown in Esty and Porter (2005), who claim that better environmental outcomes are a result of competitiveness, when it appears that the same attributes that determine competitiveness (such as better institutions) also influence environmental outcomes.

In tandem with these different and varied definitions, there have also been devised several ways in which to measure the competitiveness of a country. Early critiques by Buckley et. al (1988) on the difficulties of creating a uni-dimensional measure for measuring competitiveness (such as the number of patents granted in a single country, a metric favoured by Furman et. al 2002) resulted in a slew of multidimensional indices under the aegis of the World Economic Forum (WEF) and, to a lesser extent, the World Bank. These new generation of indices have not been without their detractors: most notably, Lall (2001:1501) issued a scathing review of the WEF's Global Competitiveness Report (GCR), calling its "qualitative measures... vague, 
redundant or wrong [with] weak theoretical and empirical foundations." Difficulties with measurement can still be traced back to the methodological underpinnings of national competitiveness, however, as the indices each reflect a certain conception of "competitiveness." The real issue is not with the indices per se, but again to the confusion on what competitiveness really is.

\section{Beyond National Competitiveness}

This reality has formed the basis of several criticisms made at the idea of national competitiveness, with a key stumbling block in the theoretical conception of competitiveness being simply the fact that too much emphasis has been placed on competitiveness at the level of the country. The economics profession has been the first to take up this critique, with Krugman (1994) calling competitiveness a "meaningless word when applied to national economies." While this point was debated almost immediately from the moment it was published (see Dunn 1994), it has some merit. In particular, the shifting patterns of globalization and general lowering of barriers (especially within a customs union or free trade area) means that spatial competitiveness may not necessarily correspond to country borders (Omae 1995), so to talk of national competitiveness is to ignore the fractals of competitiveness that are occurring at other levels than the nation-state. ${ }^{1}$

There has been extensive work done on regional and spatial agglomeration (Malmberg et. al 1996) that examines the "cluster" effects of businesses, and how firm competitiveness can be enhanced via proximity. Indeed, as Maskell and Malmberg (1999a:167) note, "proximity between firms plays an important role in interactive learning processes and that knowledge creation is supported by the institutional embodiment of tacit knowledge useful for particular classes of activity." Gugler and Brunner (2007) also emphasize that clustering and location can play an important role in attracting FDI, which then can result in increased competitiveness; the benefit of clustering is that it can increase the absorptive power of the host country in the aggregate, but in reality the use of FDI is conditioned on very localized conditions.

However, this work has rarely considered the cross-border aspects of competitiveness, which also benefit from proximity, albeit oftentimes with artificial barriers that can impede cooperation. This does not mean that such regional agglomeration has not occurred: in places such as the Russian-Chinese border, "cross-national growth zones" (Chen 1995) have begun to flourish, as low-cost zones have benefited from the diffusion of ideas that can then be implemented more cheaply than in developed economies (Maskell and Malmberg 1999b). But the understanding of such regional competitiveness is still in its infancy, as it marries both the national-level conception of competitiveness with the more micro, firm-level belief in market share, leading to sometimes confusing analyses of regional factors (Bristow 2005). More importantly, the competencies and knowledge embedded in regional growth are themselves an outgrowth of complex historical and societal factors, meaning that regional competitiveness can be accepted as a fact but its replication (especially to the national level) is difficult to accomplish in practice (Boschma 2004).

Beyond the move downward to micro-level competitiveness, there also has been a slow move towards understanding the source of competitiveness in larger trading blocs such as customs unions or free trade areas. How would an international organization such as a Customs Union

\footnotetext{
${ }^{1}$ Chikan (2008) also noted that there is little correspondence in the literature between the macro-level and microlevel conceptions of competitiveness, meaning little understanding of how one would lead to the other.
} 
or a Single Economic Space help to foster competitiveness in the member states of the organization? Cho (1998) argues that this may be a false question, as the determinants of competitiveness are standardized, no matter which level of aggregation is examined; thus the ideas of physical and human capital innovation can be scaled up to the level of regional trading blocs (and the world) as well as scaled-down to firms and cross-border interactions. However, competitive advantages that are inherent or nascent within a country can be further aided by the liberalization that accompanies the creation of a trading bloc. As noted in the introduction, market access, free factor mobility, and greater ability to access FDI are some benefits of regional liberalization, and a country that already has an advantage in human capital (for instance) can expect to see a boon in competitiveness from integration (Marques and Metcalf 2005).

Along these lines, Gehrels (1956), in an early article, also makes an interesting point regarding the formation of customs unions, in that the lowering of internal barriers can increase competition within the bloc, which is thus better for driving the competitiveness of the bloc as a whole (if not to the specific firm that is unable to compete). However, Corden (1972) also shows that customs unions can lead to less competition, and thus less competitiveness, as governments attempt to eliminate all but one producer in each economy, encouraging amalgamation in order to "foster competitiveness." Fung (1992) also shows that price differentials, especially related to labour-unit cost, may also influence the competitive gains from regional integration.

In addition to effects on the competitiveness of firms, regional organizations such as trade blocs can also influence internal institutional development to enhance competitiveness. Garrett (1992), examining the creation of the EU's internal market, showed how increasing integration made a country's individual incentives for protectionist policies much lower, encouraging governments to focus on creating better policies for competitiveness. The macroeconomic coordination that often accompanies the creation of a trade bloc also helps to lower transaction costs, a trait noted by Barry (2003) in the context of Ireland's performance in the EU. Finally, trade blocs may encourage effective external policies that feed into competitiveness: Yi (1996) shows that competitiveness can be improved within and by a regional trading bloc if such a bloc adopts an "open regionalism" approach that does not unduly discriminate against non-bloc members, thus allowing firms within the country to benefit from technology transfer and trade.

In sum, the area of regional and intra-bloc competitiveness is a fruitful one for research, but as Cho (1998) notes, it shares many commonalities in terms of what makes a region, bloc, or firm competitive. Thus, many of the same tools that have been applied throughout the literature in examining the competitiveness of firms or nations can be applied in evaluating the competitiveness within a customs union. Evaluating one in particular, the Eurasian Economic Union of Russia, Belarus, Kazakhstan, and Armenia, is the purpose of the rest of the paper.

\section{Creating the Eurasian Economic Union}

The Eurasian Economic Union began a road towards customs union in 1995, as Belarus and Russia entered into an agreement promising to establish a union between the two countries. This agreement expanded to encompass Kazakhstan and Kyrgyzstan in the middle of 1996, with Tajikistan joining in 1998. Movement towards making the provisions of the agreement a reality 
took another step forward in October 2000, as the "Customs Union" was transformed into the Eurasian Economic Community (EurAsEC) amongst the signatory countries. This transformation into a "Community" both streamlined and multiplied the alphabet soup of integration organizations, as the Central Asian Cooperation Organization (CACO), comprised of all Central Asian countries (except for Turkmenistan) and Russia merged with EurAsEC in 2005 (with Uzbekistan officially applying to EurAsEC as a member in October 2005).

At the same time, however, the core of the customs union as desired by EurAsEC was to be a "Common Economic Space" (CES) amongst Russia, Belarus, Kazakhstan, and Ukraine. Agreed upon in September 2003 with a signing by the presidents of these countries of the "concept agreement," this initiative was short-lived due again to political events in the region. In particular, the CES was suspended in 2004 due to the "Orange Revolution" in Ukraine, which led policymakers in Ukraine to look suspiciously upon greater integration with Russia (a stance vindicated by current events). Further piecemeal attempts for integration from 2005-07 were mostly smaller-scale, including the aforementioned absorption of CACO in 2005, the founding of the Eurasian Development Bank in 2006, and agreements on gas prices and shipments from Russia to other CIS countries.

After many false starts, 2007 saw broad leaps forward in integration amongst the countries of the $\mathrm{CIS}$ as the languishing customs union created the "Agreement Establishing a Common Customs Territory and the Customs Union" signed on October 6, 2007 between Russia, Belarus, and Kazakhstan. This new agreement with a pared-down trio of countries put into place a timetable for creation of the Union and created a Commission (the Customs Union Commission, or CUC) to oversee key issues of integration. This was followed by a flurry of legislation in December 2008 that delineated the types of customs procedures and customs regimes, procedures for goods customs declaration, and the formation of a legal environment for customs union within the larger overarching framework of the EurAsEC/EAEU (Krotov 2011). The CUC held its first session in February 2009, and a common customs tariff was agreed upon by October of that year; by January 1, 2010, the common tariff was enacted by the three countries, signaling that the customs union was officially underway. With this milestone under their belts, the presidents of Russia, Kazakhstan, and Belarus re-announced the creation of a single economic space, to comprise the three countries, by January 1, 2012.

The pace of integration has accelerated since 2012, driven by Russia's geopolitical perceptions of competition with NATO and the EU, political developments in Ukraine, and the general shift away from the West and towards emerging markets from Russia in the wake of the global financial crisis (Hartwell 2013). On January 1, 2015, the EAEU came into being, followed closely by the formal accession of Armenia the following day (Kyrgyzstan still needs to ratify the articles of accession). Concurrently, the EAEU has also begun to develop as an international organization, building on the CUC to create a Secretariat with a specific set of responsibilities. These responsibilities, building on a deeper view of integration, have pushed for a harmonization of trade policies and trade policy-making within the bloc, but also have widened beyond merely a focus on trade issues.

As Vinokurov (2013:19) notes, part of the EAEU's plan for "pragmatic integration" is to "devise a comprehensive and coordinated programme for long-term economic development and improved competitiveness, both on the national level and for the [Union] as a whole." This would entail not only a single trade policy amongst bloc members, but also coordinated scientific and technological policies by single members, overseen by the EAEU's Secretariat. 
This move towards improved competitiveness realizes that the gains from internal liberalization may only be a one-time advantage, and, while "creation of the Common Economic Space is an important condition for further competition within it... it does not guarantee higher competitiveness of Customs Union and SES enterprises in the world markets" (Bordachev et al. 2013). More importantly, it expands the remit of the EAEU beyond its role as a trade secretariat and allows it to encompass the full gamut of issues related to national and international competitiveness.

\section{Forging Competitiveness in the EAEU: Strengths, Weakness, and Opportunities}

Given the current boundaries and planned expansion of the EAEU, and its move away from trade and into competitiveness, what are the prospects for actually increasing the international competitiveness in the members of this regional bloc? Does the EAEU as an institution allow for capturing the differing ideas of competitiveness shown in Section II? In order to analyse these questions, this section utilizes a standard tool of the management literature, a strengths, weaknesses, opportunities, threats (SWOT) analysis, to examine the EAEU as it stands right now. As will be shown, the bloc has much to recommend it as a vehicle for completing the transformation of the economies of its member states, but there also remain many obstacles that may impede the ability of the EAEU and its member states to reach a higher level of competitiveness.

\section{Strengths}

Starting from the strengths of the proposed Single Economic Space, there are many positive attributes of its member countries that the EAEU can build upon in order to push for more global and regional competitiveness, including:

\section{- Geography: becoming the world's hub}

Dubai has been able to cultivate an economy over the past two decades as a trading center, a place where east and west meet briefly then continue onward (Hvidt 2009), and built upon those logistics to blossom into a tourist destination as well (Lohmann et. al 2009). Located in an advantageous geographic position en route from Europe to points south and east, the United Arab Emirates have turned a lonely fishing outpost, surrounded by barren desert, into an unlikely commercial hub (Pacione 2005).

The EAEU has a similar advantage in its location, as its position astride Europe and Asia can forge a similar link between Russia, East, Southeast, and South Asia, and the Middle East. A first advantage may be cultural: Kazakhstan's leader Nursultan Nazarbayev has repeatedly stressed that his country is a "snow leopard," an animal that has traits of both East and West encapsulated within (Hanks 2009) and implying that Kazakhstan is a point where both cultures mingle. Indeed, the sheer expansiveness of the Eurasian land space means the opportunities for micro-linkages across borders (internal and external) are enormous. The diversity of cultures encapsulated within the Russian Federation alone (at last count, 185 different ethnic groups were living in Russia's borders) can also help to forge these linkages, driving competitiveness at a regional level. This has already begun to happen somewhat in relation to China, as minorities in the west of China have played an increasing role in trade relations with 
the Central Asian countries (notably Kazakhstan, see Laruelle and Peyrose 2009). The ethnographic mix in Central Asia in particular lends itself to this cross-border competitiveness, and should be encouraged by policymakers within the EAEU.

These cultural advantages could also translate directly into broader economic and competitiveness advantages, given the amount of trade that passes between neighbouring states (for example, the EU estimates that it now has a value of trade over $€ 1$ billion a day with China). The leaders of the member states of the EAEU are aware of this possibility, and have been speaking of a "New Silk Road" for years; however, in order to make maximum use of the geographic advantages of the EAEU, the bloc would need to prioritize openness and ease of pass-through rather than a protectionist attitude towards countries outside of the bloc. This would also require developing customs administration that is welcoming, rather than suspicious, of international commerce, and that moves towards risk-based monitoring (Krotov 2011). Put simply, the EAEU would have to develop competitiveness in trade facilitation in order to derive broader economic competitiveness. Coming back to our example of the United Arab Emirates, the UAE is acknowledged by the World Bank's Doing Business rankings as having one of the best business climates in the world, with the restrictions on trade placing it in the top 10 of all countries. For the Customs Union to garner the same benefits from geography as Dubai enjoys, it would have to remove the man-made barriers to trade (Isakova et. al 2013) and display a political will that has thus far been lacking (Tarr 2012).

\section{- Natural resources}

If there is one area of the economy that the EAEU already leads the world, it is in natural resources, especially in regards to extractive industries. Russia is the world's largest oil producer (and Kazakhstan is the world's $17^{\text {th }}$ largest), while in natural gas Russia only trails the United States in production with Kazakhstan relatively farther behind (approximately $30^{\text {th }}$ in the world, behind Venezuela). The creation of the EAEU has already helped to increase the competitiveness of Russian oil and gas in Central Asia vis a vis China, a position that was eroding in 2009-10 due to China's relative resilience in the face of the global financial crisis (Cohen 2013). With the prospect of other Central Asian countries possibly joining the Eurasian Union, the vast energy resources of the region can be brought into one similarly-oriented grouping, helping to reduce transportation and other transaction costs to bringing these goods to market.

However, the EAEU may have also gone as far as it can in garnered natural resource competitiveness, as two of the largest gas producers in the world (Turkmenistan and Uzbekistan) remain resolutely outside the EAEU's umbrella. Moreover, unlike other types of business or economic activity, which can see cross-border or regional competitiveness, natural resources remain very much based at the national level (although regional competitiveness can be improved by a resource bonanza, as the shale gas revolution has shown in the state of North Dakota in the US). This has been a constant theme in the development of the vast energy resources of Russia (and before that, the Soviet Union), where much of the bounty was located in inhospitable climates or inaccessible regions; no one speaks of Norilsk as a "boom town," and it is likely that there will be little regional competitiveness effects of the increased natural resource production.

- Human capital 
It is well-known that a country cannot remain competitive without a highly educated workforce (Delmar and Davidson 2000), as an educated populace can increase high-tech exports and drive innovation. Moreover, recent research shows that disparate levels of human capital can account for differences between economic performance in different regions, with higher levels of education helping regions to develop faster than regions with lower levels or quality of human capital (Gennaioli et. al 2013).

Even in the days of stagnating productivity in the Soviet Union, the scientific academies across the country were well-known for their ability to turn out highly proficient scientists and engineers. This trend has continued to this day, with $76 \%$ of eligible-age children enrolled in tertiary education in Russia in 2010 , as compared to $26 \%$ in China or a mere $18 \%$ in India (Maskus 2012). Russia does not quite score as high as OECD countries in international educational comparisons, as evidenced in the OECD's Program for International Student Assessment (PISA) from 2009, where Russian students placed $38^{\text {th }}$ and $39^{\text {th }}$ in the world in mathematics and science respectively, but this was still enough to place them higher than countries renowned for their innovative edge, such as Israel or the UAE.

While Russia is perhaps the most well-known example of the emphasis on higher learning, Kazakhstan has also made a concerted push into increasing the quality of its workforce, with initiatives such as Nazarbayev University attempting to attract the best and brightest and reverse a decade-long decline in educational quality in the country (Shagdar 2006). Indeed, the country has been on an upward trend in shedding the most harmful aspects of the Soviet educational system, the perception (or reality) of corruption and grade-buying. According to Heyneman et. al (2007), the influx of foreign educational institutions into Kazakhstan during the 2000s helped to reduce the incidence of corruption and has increased the quality of educational attainment. These initiatives may help foster the workforce needed to push an innovation-based economy.

\section{- Speaking the same language}

In much of the world, the language of commerce is English, often spoken by people who do not have it as a native tongue; indeed, it is common to find a Malaysian speaking to a Finn speaking to an Albanian speaking to a Spaniard in English, mainly because there English remains the common link, even though none of them counts English as their mother tongue. In the three official members of the EAEU, as well as among the associate or candidate members, Russian is spoken as a first or second language. Sharing a common language, as well as the cultural attributes associated with that language, goes a long way towards reducing transaction costs and breaking down other barriers that may exist in forging cross-cultural links, especially in regards to Russian's effectiveness in the region (Fidrmuc and Fidrmuc 2014). Moreover, the elites in Belarus and Kazakhstan for the most part were trained in Moscow, and still have a network of contacts in Russia that can be relied on for either business or political dealings. This shared experience of language and linkages has been proven in the economic literature to be a powerful motivator of differentiated trade (Rauch 1999), and may also help to create a base of intra-Union trade that can benefit each member of the EAEU. The shared linguistic and cultural experiences may also help to expand the EAEU to other post-Soviet countries, adding more potential consumers at a low marginal cost in regards to cultural barriers (Rauch 2001). This can allow firms within the Union the ability to compete more easily in these new markets than non- 
Russian speaking firms, as well as increase the ease of micro- and cross-border competitiveness due to linguistic ease.

\section{Weaknesses}

Arrayed against these strengths are a large number of weaknesses that call into question the EAEU's ability to promote competitiveness, whether at the traditional, national-level, or at a more refined local or cross-border level. Indeed, as we will see, many of the strengths that the EAEU holds now in terms of its competitiveness may also be weaknesses in the longer run.

\section{- Geography is also a curse}

While the location of the Eurasian Union enables it to play a role as a bridge between west and east, the topography of Central Asia and the remoteness of much of the Union itself makes this bridge difficult to traverse. Infrastructure links between the interior of Russia/Kazakhstan and the rest of the world have improved over the past decade, as has linkages between the Russian far east and the rest of Asia, but transport costs still remain high (Raballand et. al 2005), and infrastructure is both of poor quality (Grigoriou 2007, Singla 2014) and oriented almost exclusively towards Russia and Europe (meaning that there still are barriers to trading with China, see Raballand and Andresy 2007). For innovators and entrepreneurs that are based in Ulan-Ude or Karaganda, there are much higher barriers to bringing ideas to market than those in Moscow or Minsk; this difficult rises for manufactures, which are subject to the difficulties of transport, remoteness, and still relative underdeveloped trade links with the rest of the world (Dowling and Wignaraja 2006). These issues constraining competitiveness will only rise if Armenia and Kyrgyzstan join the EAEU: Armenia faces closed borders on two sides, while Kyrgyzstan's growth in trade has been almost entirely due to its policy of liberalization and not because of a lowering of natural trade costs (Kurmanalieva 2008).

Beyond the natural difficulties posed by geography in Central Asia, political and economic realities on the periphery of the EAEU also makes cross-border regionalism much more difficult. Russia spans so much of the world's territory, supplemented by the borders of Kazakhstan and Belarus, so there should be ample opportunity for cross-border collaboration and regionalization. However, this is hardly the case, as the levels of instability on the Union's borders are legion: from Ukraine and Moldova in the west, undergoing conflict, to the economically unstable (and ethnically fragile) Central Asian republics and Afghanistan to the south, to the tightly controlled Chinese border to the east, the Union has very little in the way of good neighbours. There is ample economic evidence of the deleterious effects of regional instability (Ades and Chua 1997), and continued conflict on the periphery (or even within Union members, as evidenced by the Muslim insurgency in Dagestan) can continue to damage the competitiveness of the Union as a whole. In these instances, micro-instabilities (even if localized to particular regions) can have a multiplier effect far beyond immediate border regions.

- Simultaneous worries about similarity of exports and lack of complementarity in other areas

With $68 \%$ of Russia's export revenue derived from oil and gas, and $50 \%$ of Kazakhstan's economy reliant on hydrocarbons, there is no doubt that the economic growth of the EAEU is 
driven by oil. But while these two largest members of the EAEU may be competitive internationally in oil and gas production, there is a growing acknowledgement of the need to diversify the economies of the EAEU in order to sustain growth and encourage competitiveness. Reliance on natural resources has been documented to affect national-level competitiveness in a negative way, mainly through Dutch disease and political economy effects (van der Ploeg 2011). As Sachs and Warner (2001) show, the price effects of natural resource dependence harms exporters, who obtain materials domestically and sell in international markets, with rising price levels rendering exporters uncompetitive internationally. While there is some evidence that natural resource abundance will increase the amount of inward FDI (Narula and Wakelin 1998), this investment flows only to the resource industries and there are little spillover effects (van der Ploeg 2011).

This effect has surely been seen in the EAEU countries, with inflation averaging $9.3 \%$ in Russia over the past ten years and contractions in the non-tradable sector in agriculture and light industry relative to the natural resource industry (Cordonnier 2005). While Oomes and Kalcheva (2007) argued that Russia had the symptoms of Dutch Disease but that the jury was out on whether it actually existed, the evidence since the global financial crisis points more and more to it being a pervasive problem. In terms of foreign investment as well, while FDI has become more diversified during the global financial crisis, a full third of all inward FDI in Russia goes to the extractive industries; indeed, between 2001 and 2006, the Sakhalin Region attracted $30 \%$ of all incoming FDI by itself, due to vast oil and gas reserves (Strasky et. al 2012). This reality shows that, even beyond the national-level effects, resource reliance can have deleterious regional consequences on competitiveness (as well as increase political pressures, as demonstrated in Heslop 2003). Simply put, the emphasis on oil and gas can crowd out competitiveness in other areas, a fact that has been seen in the patterns of production in Russia and, to a lesser extent, Kazakhstan.

\section{- A Ubiquitous Top-down Approach}

Geography and resource-dependence are in some way natural phenomena, out of the control of policymakers, but the EAEU has been plagued with policy shortcomings as well that threaten long-run competitiveness. One of the most crippling has been a tendency towards centralized planning of innovation, rather than allowing innovation to emerge organically. This lingering vestige of central planning has been organized ostensibly to spur competitiveness, but in reality, it may have the opposite effect.

Russia, under Putin in particular, has exhibited a love affair with government-led investment to drive innovation and growth. "Mega-projects" such as the Sochi Olympics or the revitalization of Vladivostok for the 2012 APEC Summit have diverted government investment and crowded out private investment (Pilipenko 2013). Moreover, the concept of "national champions," advanced by President Putin in his PhD thesis and subsequent articles in the late 1990s, has been explicitly made the centrepiece of Russian economic policy; this concept, with roots in industrial policy, pushes for vertical integration of large corporations under state guidance, serving a national goal (rather than profit maximization) and driving national competitiveness. This approach has led to a distinct stratification in Russian business, with mega-corporations such as Gazprom and Sberbank facing little competition from mid-sized companies, but a large proliferation of businesses at the micro- and small-enterprise level. 
Similarly, while Kazakhstan has made greater strides in fostering an environment for business entry (see below), there is still a tendency towards aggregation at the top. In particular, Samruk-Kazyna, a joint stock holding company founded in 2008 by the decree of the President, holds shares in most major companies in the country (including airports, utilities, and gas and oil production) and in turn has only one shareholder, the government of Kazakhstan. This mixture of state-owned and privately-held governance structures means a fair degree of political interference in pursuit of "national economic priorities" (Kalyuzhnova and Nygaard 2011), as well as domination of the investment within the country (Peyrouse 2012).

However, as shown earlier, competitiveness is a process of innovation and incremental change, allowing for an economy of any scale to outperform others. Unfortunately, the innovative process requires trial, error, and failure (Miles and Snow 1994) in order to achieve success, and the top-down planning that pervades the EAEU at present is not conducive to this innovation. Indeed, the success stories that have emerged in the EAEU space have come about where neglect was the active policy. A key example of this is the microelectronics industry; originally driven by political and military imperatives under the Soviet Union, the Russia microelectronics industry had to thoroughly restructure and reinvent itself over the past 20 years, a process that has been helped by lack of government interference (Smith 2002). Allowing for these organically-produced "winners" to emerge rather than using top-down planning will result in both more and more sustainable innovation, which in turn feeds competitiveness.

- Lack of coordination in most areas...

As noted elsewhere (Hartwell 2013), and as the European Union has found out so bluntly over the past decade, a key sticking point in greater integration beyond the trade realm for the EAEU is macroeconomic coordination. Defined by Begg et. al (2003:66) as "supranational rules or norms which are agreed by all Member States, leav[ing] primary responsibility for the policy area with national authorities, but setting limits on their discretion," policy coordination has long been championed within the European Union as a necessary (but difficult to construct) facet of the European Project (Eichengreen et. al 1998). To put it bluntly, integration of trade, capital, and labour flows requires at least a modicum of coordination of macroeconomic policies to avoid fiscal or monetary imbalances, lessen trade disputes (Shadikhodjaev 2009), and help to achieve economic goals (see Baer et. al (2002) and Malamud (2005) for what happens when coordination does not accompany integration).

This reality also extends to competitiveness, as disjointed macroeconomic policies in a realm of free movement of capital and labour can also cause competitive disparities within and for the businesses in a trade area or customs union. While Gros and Alcidi (2010) argue (to some extent correctly) that that changes in competitiveness are endogenous and largely outside of policy control, work from Rana (2007) has shown, in regions with tight integration (in his case, East Asia), business cycles also tend to synchronize, meaning that divergence in macroeconomic policies can cause disproportionate competitive effects. ${ }^{2}$ This effect is even more pronounced at a regional and cross-border level, as macroeconomic policies that can have large disparate influence on prices or labor costs will discourage cross-border cooperation between universities or firms engaged in R\&D; this has been supplemented, at least in the EU, by generally weak coordination in public innovation policies (Kaiser and Prange 2005).

\footnotetext{
${ }^{2}$ Moreover, Gros and Alcidi (2010) tend to focus on unit labour costs as their measure of competitiveness, which is a very narrow definition.
} 
Thus, it is plain to see that some level of macroeconomic coordination is necessary with deeper integration (although there is still much controversy on what the "optimal level" should be), but this coordination will also not happen on its own. Indeed, one of the issues that the European Economic Community (EEC, predecessor of the European Union) pledged to create in the Treaty of Rome was a common market free from distortions to competition (Hermann 2007). However, in the EAEU, beyond the trade coordination (as we will see below), there has been little progress made in any other policy, despite a slew of agreements pledging to seek such coordination (Vinokurov 2012). As Hartwell (2013) notes, monetary policy coordination is nonexistent in the EAEU countries, with inflation rates only converging due to other independent (and mostly global) factors, Moreover, exchange rate divergence has actually worsened over the past year, with Kazakhstan unilaterally devaluing the tenge in February 2014 in response to the Central Bank of Russia's policy of a managed depreciation of the ruble.

In fiscal matters, there is similar lack of progress in forming a united front due to the overwhelming incentive for the EAEU members to cover budgetary shortfalls with protectionist measures rather than reducing spending (Vinokurov and Libman 2014). As Vymyatnina and Antonova (2014) reinforce, any fiscal coordination that occurs is purely by coincidence rather than by conscious design. This approach to competitiveness has also favoured national companies rather than companies throughout the EAEU, meaning more of a focus on "national champions" rather than "EAEU champions." Finally, the sheer size of government in the member states of the EAEU may be limiting further coordination a priori, as the "optimal" levels of coordination are in turn influenced by the national policies pursued by each government (Herzog 2006). This may present EAEU countries with a difficult conundrum, as they are better off pursuing less coordination (and risking lower competitiveness) if they already have chosen to have a much larger government apparatus.

- ....and too much coordination in others

While much of the macroeconomic integration necessary for increased competitiveness is missing in the current Eurasian Customs Union, there has been remarkable progress in an area that has unequivocally harmed competitiveness: tariffs. As a customs area, the EAEU already has no internal tariffs amongst members, thus easing the way for regional cooperation within the bloc and possibly helping to create interlinked industrial systems (so necessary to create higher technology products). However, as noted above, the similarity of output amongst members means that many of the trade gains that would come from liberalization would come from trade from outside the bloc. Unfortunately, the EAEU's common external tariff has been set to the other extreme and is sabotaging any gains that come from internal liberalization.

Part of this issue comes from a reality noted in Hartwell (2013), mainly that, rather than fashioning a new trade regime from the best parts of the constituent members, the EAEU has instead chosen to extend the Russian tariff regime to all, with over 80 percent of the original tariff schedules copied directly from Russia (Wisniewska 2012). As Heal and Mladenovic (2014) note, in Kazakhstan alone this reality will result in external tariffs on a trade-weighted basis doubling from 2009 to 2015, a situation that the landlocked country can ill-afford. At the same time as members were uniting in terms of external taxes, they were also closing loopholes, reducing the number of exemptions from the tariff for Kazakhstan from some 400 to 70, meaning more goods were subjected to tariff than previously (Dragneva and Wolczuk 2012). ${ }^{3}$

\footnotetext{
${ }^{3}$ Of course, from a political economy perspective, there should be a limited number of exemptions from any tariff regime, as it creates rent-seeking and lobbying opportunities (especially in an environment where institutions are
} 
Early assessments of the results of the effect of the imposition of the common tariff have been negative: as predicted by economic theory, while intra-EAEU trade has increased somewhat due to the lowering of barriers internally, while external trade has slowed (albeit at a smaller scale, an effect that Mkrtchyan and Gnutzmann (2013) put down to tariff increases being targeted towards sectors with relatively inelastic demand). However, more important in regards for competitiveness, Mkrtchyan and Gnutzmann (2013) also find that the price effects of the external tariff have begun to bite, with Kazakhstan seeing increased prices of goods from China (due mainly to tightening of the border with Kyrgyzstan, which was a conduit for Chinese goods).

The higher prices to be found in EAEU members for imports may appear to be a boon for competitiveness, but in reality, these foreign goods act as inputs or intermediate goods to many EAEU industries, meaning that increases in their prices will result in higher final prices emanating from the EAEU. This strikes directly at the idea of competitiveness. Similarly, the erection of such a solid external tariff (and the concomitant tightening of border controls) also makes regional competitiveness very difficult in an area where there may be excellent economies of scale in cross-border cooperation, namely land-locked Central Asia. The EAEU approach has also conflicted somewhat with the WTO commitments made by member states in the process of their accession, an institutional conflict that has yet to be resolved (Heal and Mladenovic 2014).

Finally, and perhaps most importantly, the largest effect of strong tariffs for competitiveness in relation to EAEU firms is directly related to the historical experience with "infant industry" approaches, where small, fledgling companies were supposed to be able to grow behind a wall of protection until they could compete internationally (Chang 2002). In reality, however, infant industries did not grow, because they became addicted to the protection, a situation that was repeated over and over in every cultural setting, in every country (Panagariya 2011). This meant that more time was spent lobbying for protection than in seeking innovation or competing on the world stage, with a result of, when liberalization finally did come, foreign firms being able to do the job cheaper and more efficiently. This is precisely the opposite of what the EAEU wishes to achieve.

- Lack of management abilities and need to improve firm and industry level competitiveness

Of course, the growth of firms in a competitive economy is shaped by the philosophy towards such firms or the macroeconomic environment (as shown above), but also by the inputs to these firms and the conditions in which firms in a country operate in reality. In regards to inputs, while the result of the educational initiatives in Russia and Kazakhstan noted above may create a deeper pool of educated workers, able to drive innovation or become the next great entrepreneurs in high technology, there is a growing literature that shows that education is not the only determinant of entrepreneurship (and thus competitiveness). Indeed, work from Lee et. al (2004) and Lazenby and Machaba (2011) shows that college graduates are actually less likely to become entrepreneurial, as sacrificing the stability of regular employment would invalidate the very investment they made in going to university. Larger studies and reviews of

weak). However, in the case of Kazakhstan, as during communism, it was the breaches of formal rules that actually helped the economy to run; closing these loopholes makes it more difficult for Kazakhstan to import the goods it needs. 
the literature have also found a positive correlation between entrepreneurial success and education writ large (see especially Dickson et. al 2008), but less need for advanced tertiary education as opposed to broad-based skill sets.

This research only focuses on broader based liberal-arts education at the tertiary level, and not necessarily on schooling that is tailored towards business education. Here, research is thinner on the ground, but there is some evidence that greater business training opportunities, both at the formal and informal (on-the-job) level, can help to improve innovation and competitiveness (especially when combined with prior business experience, see Raymond et. al 1993). Business schools can provide a "sorting function" for businesses by weeding out employees who may not have the right skill set or fortitude to succeed in business (Pfeffer and Fong 2004), while also highlighting those who have the predisposition to be successful businesspeople (Florin et. al 2007). Education has also been linked with entrepreneurial success and firm competitiveness in the former Soviet Union, especially in Ukraine (Solesvik 2013).

Even looking at this narrower scope, however, one can see a great divide between Western Europe and the EAEU member states (Varblane and Mets 2010). Managerial acumen is, for the most part, lacking throughout the former Soviet Union, a trait that was observed as early as 2002 (Ardichvili and Kuchinke 2002) but has persisted (Holden and Vaiman 2013). These problems are not merely at the surface, for, as Holden et. al (2008) note, even the translation of marketing terms into Russian have been problematic and expose a deeper scepticism with Western ideas of business. Holden and Vaiman (2013) also highlight the fact that talents that are valued by Western managers are culturally denigrated by Russian managers, making them wary of talent rather than utilizing it to its full potential. While a full-scale cultural shift is unlikely in coming years, the EAEU suffers from the inherent gravitation to authoritarian rule typified in its political culture, and which has permeated its business culture; this has in turn led to ossified management structures and lack of initiative, which could push forward innovation and competitiveness.

- Common language - can it grow beyond a Russian-speaking area?

In a similar vein to the issue of business education is the question of ability to communicate with the outside world. While the use of a common language in the current and prospective member states of the EAEU is a major strength and a way to reduce transaction costs, it is also somewhat limiting in that it can create complacency. In particular, operating in your native language when it isn't the language of international commerce does not force managers to think outside their standard cultural milieu and understand the exigencies of different markets. The example of the European Union can make this clear, where the reality of traveling 500 kilometres and being in an entirely different country with a language wholly unrelated to your own helped to make European firms more global and accepting of diversity; moreover, it helped to speed the spread of English as a common language, allowing for more global interaction at the same time as it eased intra-European interactions.

Russia, on the other hand (and to say nothing of Belarus), has shown difficulty in moving into markets beyond its comfort zone (apart, of course, from its sale of oil). Emblematic of this is the fact that Russians have some of the lowest English-language skills among major economies: according to a test administered by EF Education First online in 2012, Russia scored $29^{\text {th }}$ out of 
52 countries, behind Indonesia, Iran, and Pakistan, ${ }^{4}$ while a targeted (and more scientific) retest by EF in 2013 as part of the Sochi Olympic preparations found that Russia was ranked $31^{\text {st }}$ out of 60 countries in English proficiency. ${ }^{5}$ Moreover, Russia hasn't been effective in spreading its own language beyond its borders apart from the legacy of its military expansion, with Russian language proficiency estimated at about $5 \%$ of the entire population of the EU (with higher levels in former colonies such as Latvia and Estonia, Eurobarometer (2012)). For the other large member of the EAEU, the situation is even worse: Aminov et. al (2010) estimate that only $34 \%$ of Kazakhs speak their own language fluently, with a paltry $2 \%$ of the population able to communicate in English.

This lack of foreign language abilities could become problematic if the EAEU is serious about expanding beyond the old borders of the Soviet Union. While there are surely some older Vietnamese or Indians who remember Russian from their days of fraternal brotherhood (and some younger ones who have taken the language), there would need to be a common language of communication, and that would most likely be English. Kazakh President Nazarbayev has acknowledged this issue, calling in 2013 for Kazakhs to become multilingual like Indians, Malays, and Singaporeans, with a focus on English, Russian, and Chinese as their man languages. ${ }^{6}$ However, in combination with the EAEU's tariff policies, learning Chinese may not be as important as it could be absent a lowering of trade barriers. A better approach would be to utilize the cross-border trade that already exists, where (by necessity) firms work in multiple languages, and build on this to leverage regional into national competitiveness. But as shown above, this would need an overhaul of macroeconomic and trade policy in addition to educational reform.

\section{- Disparate business environments: A Need to Learn from Kazakhstan}

The final aspect of the overall climate for competitiveness in the EAEU that needs to be improved concerns the broader idea of the "business environment," defined by the World Bank (DCED 2008) as "a complex of policy, legal, institutional, and regulatory conditions that govern business activities." Under this conception, a positive business environment can facilitate starting a business, breakthroughs in innovation, and competing internationally, while a poor business environment can both hinder business formation (Hartwell 2014) and stifle innovation (Busenitz et. al 2000). For all levels of competitiveness, it is thus crucial to have the correct institutions and legal regime in place to encourage risk-taking and innovation (and indeed, these facets of "competitiveness" are found in the WEF's global competitiveness rankings).

Unfortunately, by any metric, the EAEU countries are rarely thought of as exhibiting exemplary legal or institutional structures. In many ways, the business environment throughout the EAEU is the flip side of the top-down difficulties seen earlier, with a too-bureaucratic approach to firm creation and operation. The countries within the EAEU stratify on this point, however, with different success in creating an open business environment. For example, Russia is rightly seen as the current force behind integration, even though Kazakhstan and Nursultan Nazarbayev was pushing for greater economic cooperation from literally the moment that the Soviet Union

\footnotetext{
4 "English where she is spoke," the Economist, October $24^{\text {th }}, 2012$.

${ }^{5}$ Guennadi Moukine, "Olympic Training Puts Russia 31st in English Language Proficiency," the Moscow Times, Novemebr 8, 2013.

6 “Kazakhstan President calls people to learn English and eye Chinese and Russian for future," Tengri News, October 21, 2013.
} 
fell (Hartwell 2013). Unfortunately, Russia is perhaps the least-developed country in terms of its business environment, especially when compared to Belarus and Kazakhstan, and extending Russia's approach to doing business will only harm the competitiveness of the entire Union. Indeed, while Russia has made some noteworthy reforms in starting a business and registering property (as measured in the World Bank's Doing Business report for 2015), the country as a whole lags behind Kazakhstan and Belarus in specific indicators such as protecting investors, obtaining electricity, and resolving insolvency. Moreover, the World Bank methodology ignores large obstacles in the overall business environment in Russia, including the ubiquitous need for stamps and notarization, as well as the poor quality of the bureaucracy in the country (consistently ranked by the International Country Risk Guide, or ICRG, at the lowest level in the world).

This issue of the business environment can be seen as the flip side of the top-down nature of decision-making noted earlier, as it too can harm entrepreneurial spirit and quash innovation. However, the business environment issue is less pressing, mainly because Belarus and Kazakhstan (and even Russia as of late) have been going in the right direction. That is, there is some sense within the EAEU that business environments can be improved, and different models attempted, than in the top-down mindset chronicled earlier. The key for the EAEU is to follow the best-practices models already attempted in a place such as Kazakhstan, rather than restart the race by extending the Russian model across the Union. Indeed, a way to turn this weakness into a strength for the EAEU is to implement reforms across the Union that have not even been attempted in a member state as of yet, such as an electronic company registry or removal of all notarization requirements for land registration. By pushing the frontier of business environment liberalization at the Union level, competitiveness within all member states will increase.

\section{Opportunities}

While there are many weaknesses inherent in the Customs Union as it currently stands, there are also a number of opportunities within the diversity that already exists in the member states. Indeed, the challenge will be, as shown in the weaknesses section, in allowing for this diversity to push through the formal barriers that exist and actually drive competitiveness.

\section{- Regionalism already in progress}

The reality of such a large and diverse region within the existing EAEU (to say nothing of enlargement) means that distortions are not omnipresent; this translates into a reality that regional competitiveness is already improving and at the sub-national level, and regional solutions are being created. This is mainly happening within sub-national governments, as the policy obstacles that are noted above at the Union- and country-wide level are being tackled by regional governments who are intent on creating competitiveness within their own geographic space. In-line with the good-governance principles of "subsidiarity," decisions are being made at the lowest possible level, as local politicians and businesspeople know about the local conditions better than those thousands of miles away.

A key example of this is occurring within Russian, where various regions are functioning as a laboratory for policy change. Moscow and St. Petersburg, as the seats of power and wealth, remain some of the least innovative and most difficult places to do business in the country, but time zones away, regions such as Ulyanovsk and Tatarstan are innovating with their own 
policies (World Economic Forum 2014). Cities noted by the World Economic Forum and the World Bank's sub-national Doing Business survey as leading the charge have each made an innovation in their own way: Ulyanovsk is the number one region in Russia on the overall ease of doing business, but also is a major air, rail and road transportation hub (ranked as the $3^{\text {rd }}$ best sub-national entity in the Russian Federation in this category) ${ }^{7}$ Saransk is the easiest place in Russia to obtain electricity, with a speed that would put it on par with Italy; Kaluga has witnessed the largest growth of industrial production since 2006 of any city in Russia; and Tatarstan has the highest FDI growth in the past 5 years in Russia, a trend that has withstood even the global financial crisis. Other reforms specific to innovation and competitiveness include the growth of the "Silicon Taiga" in Siberia (Bardhan and Kroll 2006), where the privatesector is leading strong growth in offshore computing, in collaboration with local universities.

This regional experimentation has been, in some sense, a product of the geography of Russian regions, which has already determined their economic relationships. This fact of geography has also shaped their approach towards competitiveness, because Moscow has only so much information about what it's like to live life on the frontier. The reality of the need for competitiveness in a far-flung place such as Ulan-Ude or Omsk makes edicts from several time zones away less pressing. Moreover, Russian regions will continue to play a crucial role as testing grounds not only for economic reforms, but for new social models of integration, showing how the Muslim minority in Russia (already rising due to demographic trends) will further benefit from integration with their co-religionists in Kazakhstan or elsewhere in Central Asia. This too is a reality of life on the frontier, as new models are tried, discarded, or built upon.

With such a movement already apace for regionalism, it is plain to see that a model such as this can be replicated across the EAEU, becoming a basis for development of the entire Union. This would complement the issue of macroeconomic coordination noted above, as national governments would be charged with macroeconomic stability and integration (note necessarily merging) of fiscal and monetary decisions, and sub-national governments would focus on business climate issues and decentralized sectoral policies to foster competitiveness. In this manner, disparities across countries would be related more to economic advantages (i.e. regional agglomerations of labor or human capital) and less to competitive macroeconomic policies. This approach could also allow for competition of regions or member countries for highly-mobile capital (made more mobile by lowering of internal barriers) along comparative advantage lines, improving capital allocation throughout the EAEU.

- The Union can overcome political obstacles in trade

Regionalism can help to solve local problems, but many of the weaknesses noted above in the EAEU concern national policies that cannot be changed by a regional governor (trade, for example, or macroeconomic policy coordination). For the clues in changing these policies, the EAEU should not look down to the regions but should instead look up to the EAEU as an institution itself, once again going beyond the conception of the nation-state to foster the changes so crucially needed for competitiveness.

\footnotetext{
${ }^{7}$ Of course, this is relative to the rest of Russia. Seen objectively, Ulyanovsk's delays in starting a business would rank it $92^{\text {nd }}$ internationally (tied with Antigua and Barbuda),
} 
While the EAEU has thus far operated as a "treaty" organization, in that the early basis for its institutional foundation was predicated on the treaties that all members subscribed to (Dragneva and Wolczuk 2012), it can also take on the role of pushing for the consensus that may have been missing internally for liberalization. In fact, the EAEU as an institution can help to formulate and push reforms that might have been side-tracked due to political economy in one country, playing the role of scapegoat (much as the IMF or World Bank Group has done at various times in their existence, Hartwell (2013)).

Plainly put, the EAEU can act as a tool for liberal policies at the supra-national level, including involving trade, whereas the constituent members may have found it difficult politically to undertake such liberalizations unilaterally. Trade, and specifically free trade, is one of the most different policies to pursue domestically because the benefits are dispersed across all consumers while the costs fall upon often easily-definable firms and businesses. These firms then have an incentive to lobby for protection, making the political choice for free trade very difficult. But with a supranational organization negotiating treaties, that are then adopted as law, these internal political obstacles can be avoided somewhat. In this manner, the EAEU would mirror the role played by the EU in its early years, when it made a vigorous push for free trade, or even the lesser role played by other free trade areas/trading blocs such as Mercosur, EFTA, or ASEAN over their existence.

Of course, any institution such as the Commission of the EAEU is comprised of its member states, and cannot go further than the slowest member of the trading bloc is willing to go. But providing political cover through integration is a way to deal with the omnipresent difficulties that come in trade policy (Harders and Legrenzi 2008). This, in turn, can benefit the firms of the EAEU by creating the openness necessary for innovation and, most importantly, competitiveness.

\section{- An open space for knowledge}

Earlier, we discussed how the scope for intra-Union trade may be already exhausted, running near its maximum. However, this is a static analysis based upon the current capabilities of the member states and their current growth trajectories. The EAEU may change these trajectories somewhat through its removal of internal barriers, albeit not in the area of trade. More importantly could be the effect that the lowering of internal barriers to cooperation has upon facilitating knowledge transfer, including the joint acquisition of technologies and allowing for regional spill-over effects when technological breakthroughs do come about.

Much like trade in goods or services, trade in ideas also thrives when there are lower barriers or transaction costs (as in regional integration initiatives, as shown in Walz (1997)) and often follows trade into a country (Connolly 2003). And while the same difficulties to ideas entering the EAEU exist as in trade currently (and threaten to get worse under continued sanctions, see below), the lowering of barriers to cooperation within the EAEU may help to address some of the educational issue noted above. In particular, the high level of college graduates in science and engineering throughout the Union, coupled with moves towards more private institutional educations (also below), may create cross-border collaboration in R\&D and innovation that was previously more difficult. And by extending the borders of the EAEU outward, there will be more chance for interaction with the outside world, and a greater space free of barriers inside the Union, thus allowing for even greater permeation of technological ideas, innovations, and different approaches to manufactures and services. And a broader, liberal, space can take 
advantage of economies of scale to innovation that also may have been difficult in a single country. Of course, realistically, the liberal space within the largest member of the EAEU has been rapidly shrinking, meaning that this open flow of knowledge may remain an opportunity, rather than a realized strength, for the foreseeable future.

- Soft power and global image as a tool for competitiveness

The idea of "soft power" has gained currency in recent years, with various rankings and indices seeking to quantify "the ability of a nation to influence others... associated with intangible assets such as an attractive personality, culture, political values, and institutions and policies that are seen as legitimate or having moral authority" (Nye 2008:95). However, it is important to recognize that the causation from soft power to competitiveness runs in precisely the opposite direction: that is, a more competitive and thus desirable economic model is one that can generate soft (as well as hard) power. It is difficult to fathom a situation where a country can hold soft power and parlay this into competitiveness, especially since soft power is both intangible and incredibly fleeting for a country without corresponding hard power. In fact, the exercise of hard power can quickly dissipate soft power. There is no greater example of this than the effect on Russia's soft power after the Sochi Olympics, which cost \$53 billion and created a raft of goodwill for the country; a mere four days later, as Russian troops entered the Ukrainian peninsula of Crimea and annexed the region, any goodwill engendered by the Olympic games vanished quickly.

Examples like this show why Russia has scored low on many of these rankings in relation to both other emerging markets (see SIEMS 2012) and especially against more established economies (McClory 2012). With hits to both its hard and soft power in the wake of Ukraine, Russia's soft power has declined vis a vis other countries, especially in the West. Regardless, there is still an opportunity to improve this ranking for Russia and all EAEU members, especially if the macroeconomic issues shown in the last section are rectified. It appears that the quickest way for the EAEU to achieve any modicum of soft power is to focus on building up its hard power, in the economic rather than the military sphere. Providing an attractive place for investors, undertaking public relations campaigns advertising this fact (as Kazakhstan has done in major international English-speaking media), and projecting an image of openness and inclusion are all ways in which the EAEU can create soft power. This, in turn, can help attract more hard (economic) power to the bloc, by drawing in foreign direct investment and increasing joint ventures.

The idea of soft power helping to push competitiveness at a national level is of course a slow process contingent on hard power, but in regards to regional and especially cross-border microcompetitiveness, it could have a huge influence, especially when targeted away from the West exclusively. That is, while at the national level the causality runs in one direction, at the regional level, there could be feedback effects running in both directions. In particular, if the EAEU can make the changes necessary to increase economic growth and diversify economically, it is more likely that cross-border exchanges will increase. Indeed, it can be assumed in places such as the Russo-Chinese border that a more economically prosperous EAEU would lead to more desire for interaction with Russia from Chinese merchants, as well as greater proliferation of the Russian language. Hard power would beget soft power which would beget more hard power. Once again, this is predicated on the EAEU moving towards more openness, but such a situation could be seen in non-geographically contiguous regions such as the rest of the BRICS 
economies as well (with Brazil or India increasing their desire to trade with the EAEU due to a better image aided by hard power).

- Encouraging private education (and especially business education)

While, as noted in the weaknesses section, management training with the broader EAEU is lacking, it is also here perhaps that there is an opportunity to expand from the low levels that currently exist. As part of broader educational reforms, a move away from the state-run educational institution towards more private institutions can encourage the growth of private business schools, catering to the needs of future firms in the EAEU. There has been some move in this direction already in the EAEU - with the Moscow School of Management - SKOLKOVO in Russia and KIMEP University in Kazakhstan being the most notable - but a further withdrawal of the state could help to push broader business education in the Union. In particular, the role of the state in regards to education needs to be redefined from direct management and towards creating standards for educational providers, helping to ensure private providers reach pre-set criteria for their services. The opportunities for business education are huge in the combined EAEU realm, and this must be seized upon in order to better match skills and employer needs for the future.

\section{Threats}

While a myriad of external threats exist for the EAEU in general, most of them are linked to the internal weaknesses shown above. Rather than dwell on these threats to greater integration, it is important, especially in light of recent events in Ukraine, to highlight the most important threat to competitiveness in the EAEU, and this is shifts in global political imperatives, in particular, sanctions.

The EAEU has already seen economic turmoil as of the time of this writing (June 2015) from the imposition of sanctions from the EU, the US, and, perhaps more significantly, from Russia's own imposition of sanctions against the West. The plummet of the ruble and the explicit isolation of Russia from global product and financial markets have pushed an already-fragile Russian economy into recession, which then threatens Kazakhstan and Belarus (especially given that the EAEU has made the three countries more reliant on each other). This threat would be doubled if Russia were able to pressure its EAEU co-members to go along with Russia's own sanctions, voluntarily restricting imports of food from the West as a show of solidarity for Moscow's policies in Ukraine.

Indeed, there is no greater threat in the short-run to the competitiveness of the EAEU countries than continued isolation from international value chains; while, in the long run (and as championed by the current political leadership in Russia) the EAEU may be able to cultivate new markets in developing economies or in the BRICs, there is little hope of such a shift occurring in the short or even medium-term. Moreover, such a shift will also have a short-term impact on firms' balance sheets, as they need to expend the energy to find these markets, perhaps drawing resources away from innovation, R\&D, or even price competitiveness. Finally, given the capital flight from Russia during the crisis (Figure 1), access to finance will also become more difficult, a trend exacerbated by the closure of international capital markets to Russian firms. It is hard to see how these circumstances can benefit the competitiveness of firms within the EAEU. 
Figure 1 - Capital Flight from Russia

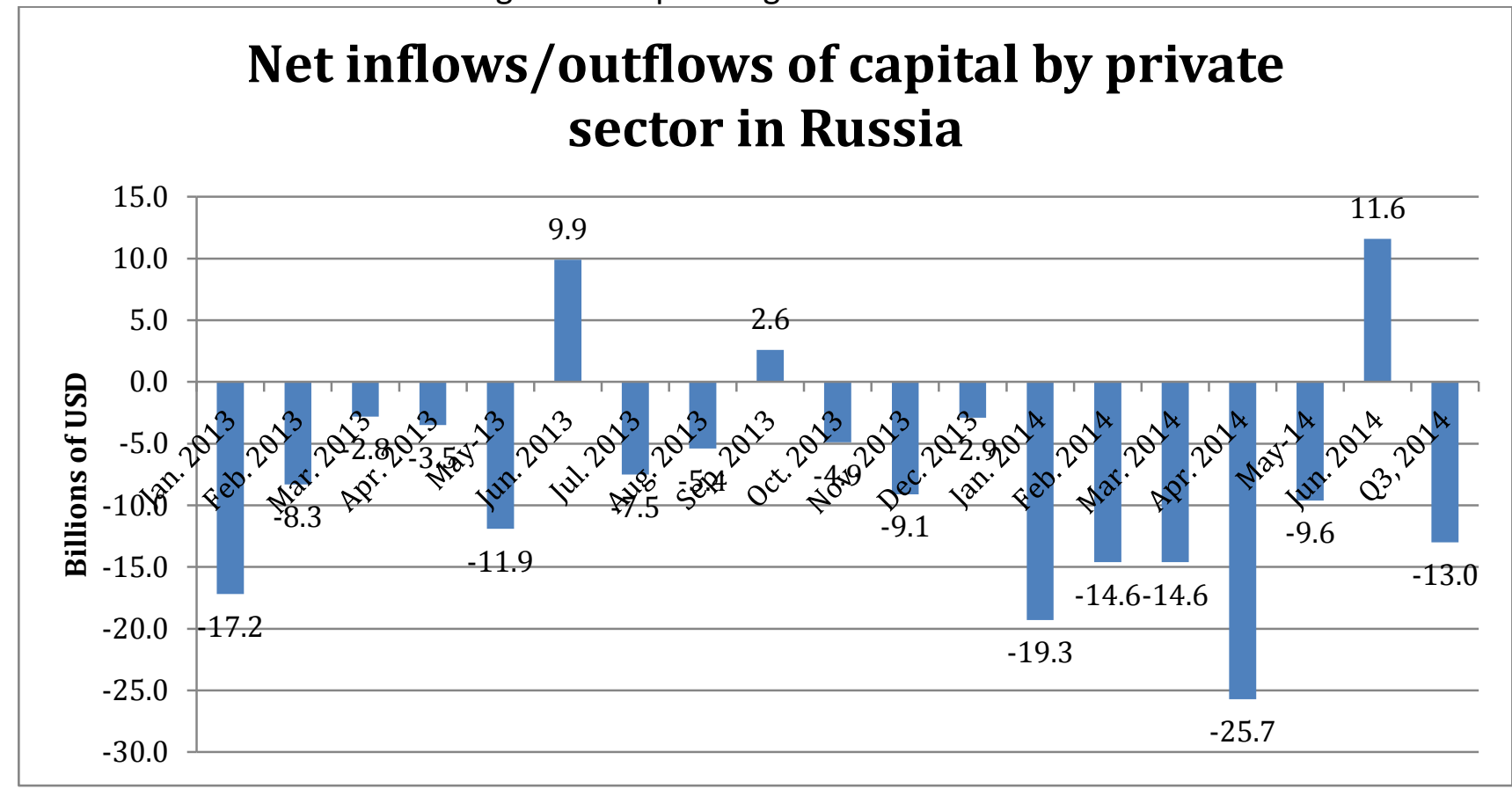

Source: Central Bank of Russia.

Of course, continuing crisis in Ukraine could also renew the push towards integration, and increase the competitive benefits that have already accrued for doing business between Russia, Kazakhstan, and Belarus. However, as noted above, integration is difficult when governments are already focused on intervening in their own economies (Vinokurov and Libman 2014); more importantly, given the fairly homogenous nature of production in EAEU members already, the benefits to removal of internal barriers may be near a maximum. Thus, the greatest threat to the economic project that is the EAEU is, simply put, politics. Without a political solution to the Ukrainian crisis, it is highly likely that integration may continue apace in the EAEU, but that it will not result in competitiveness gains for firms throughout the Union.

\section{Completing a Competitive Union}

This paper has explored the drivers of competitiveness within a Eurasian Union, and highlighted some of the weaknesses and opportunities present for improving competitiveness within the countries of the Union in the context of a changing and sometimes hostile world. As noted throughout the paper, increasing competitiveness within the EAEU will require a concerted effort by all countries in the union, as well as a focus on policies and opportunities at the subnational and regional level, plus a large dash of political will via the EAEU's own mechanisms.

In the first instance, the policies of each country in the EAEU (as well as prospective members) would need to be revamped and harmonized to compete in the new world of sluggish growth, with a focus on continued liberalization. Indeed, perhaps the key message from this analysis is that competitiveness within a Eurasian Economic Union cannot come from the governments of each member state, nor can it be driven by supra-national plans. While Belarus and Kazakhstan have made great strides in liberalizing their business environment, they are still in thrall of state-led economic development, which has not delivered competitiveness or diversification. And Russia has not even begun the process of significantly improving its business environment, 
much less moving away from politically-connected or explicitly state-run firms, which has in turn harmed its institutional development.

Rather than relying on government to push competitiveness or create "national champions," there is a need within the Eurasian Union to start driving competitiveness from the firm- and industry-level. As noted above, many of the success stories in the Union as of today are in spite of government rather than because of it, and the move away from the top-down approach will help to create stronger and more resilient firms. Of course, the ideal within the EAEU would be for Russian, Kazakh and Belarus businesses to compete, not among each other, but together with global businesses. This is a trend that may be in the cards, given the reduction of barriers within the EAEU and the increase of ease of doing business across borders; in fact, this idea of increased abilities due to the ease of factor mobility engendered by regional integration comports directly with the economic theories of integration and competitiveness. In such a scenario or increased competition and lower transaction costs, we should expect to see the fittest firms survive, who then can go forth and compete on the world's stage. The internal allocation of resources within the EAEU can be improved through process, as non-competitive firms are eliminated and society is made better off.

However, as we have seen even during the global financial crisis, this ideal will be difficult to achieve if macroeconomic policies continue to favour domestic firms and attempt to create national champions. With continued government favouritism, subsidies, and political connections creating firms too big to fail, there will be little move towards building marketdetermined "Union champions" (and likely continued move towards picking political favourites). To create the firms within the Union that can compete across the globe, the EAEU members must continue the internal liberalization of the Union, avoiding protectionism and allowing for the distribution of resources (and thus competitiveness) along comparative advantage lines.

With an eye on the future expansion of the Union, competitiveness itself may also be considered as a joining criterion for future members; as the EU showed through its successive waves of accession, EAEU membership should go to countries that are moving towards competitiveness levels of existing members and on-board with the liberal and competitive ethos of the Union. For the first steps of membership, it made sense for countries that already had strong trade and cultural (and linguistic) links to bond together, while the first accession wave may include countries that also fit this bill. But given the homogeneity of output within the EAEU even after the first wave of accession, and the relatively small access to markets that the addition of Kyrgyzstan and Armenia will bring, it is perhaps important to set criteria on who would make a good additional member to the Union. And, as noted, this could include market size, already-existing competitiveness, and/or appropriate policies.

These tenets could also apply in terms of the external economic relations of the EAEU. A key question that the Ukraine crisis has raised is, how would the EAEU relate to other economic blocs such as the BRICS? Ever since the outbreak of hostilities in Ukraine and ratcheting of sanctions from the US and EU, Russia has publicly identified itself more with the BRICS countries, including supporting the start of a BRICS "development bank." While the BRICS are indeed more diversified economically than the EAEU, apart from China, they are all showing signs of sclerotic growth linked to political ideology. There could be more gains to be made from opening the EAEU in a circumscribed way towards the BRICS countries, including as a conduit for investment and technology, but in reality the bulk of this will be driven by China. 
China does present itself as an attractive place for EAEU firms (mainly from Russia and Kazakhstan) to make inroads, especially in the micro-competitive sense. However, in order to harvest these gains, the same policy recommendations noted above need to take place, as current policies have already driven up prices of Chinese goods and invited retaliation.

These recommendations are of course focused on macro and big picture ideas, in that that they will help to foster the environment necessary for competitive firms to develop. Other policy work can be done at the microeconomic level to help staff the firms of the future, but pushing forward competitiveness at the firm-level will requires new institutions and managers. Business education, as noted in both the "weaknesses" and "opportunities" sections above, will be a crucial facet of success in the future EAEU, across all members, and thus investment should be seen targeting business education specifically. In order to better utilize these educational opportunities, universities and businesses should also explore various dialogue platforms, including involving the business community early to ensure that graduates meet their developing needs. There should also be public forums to ensure that evolving curricula, suitable for developing innovation and competitiveness, are being developed. And, of course, there needs to be a substantial increase in both educational competitiveness (through development of private educational institutions distinct from the state) and a reform in the way that state organs deal with educational institutions in the EAEU.

The state of the play in the EAEU, especially given the ongoing sanctions connected with Ukraine, is not optimistic, but the members of the EAEU have enough policy options available that can be undertaken, even with an uncertain world, that competitiveness can become a reality in the future. However, as this analysis has shown, it will require reversing course somewhat and following a road not yet taken. If the EAEU can improve its internal liberalization and adopt these same tenets in its dealing with the outside world, then there is a real chance that Russian, Kazakh, and Belarusian firms can become highly competitive. More importantly, without heeding some of these recommendations, there is little chance that this will ever come to pass.

\section{REFERENCES}

Ades, A., and Chua, H. B. (1997). Thy neighbor's curse: regional instability and economic growth. Journal of Economic Growth, 2(3), pp. 279-304.

Aiginger, K. (2006). Competitiveness: from a dangerous obsession to a welfare creating ability with positive externalities. Journal of Industry, Competition and Trade, 6(2), pp. 161-177.

Aminov, K., Jensen, V., Juraev, S., Overland, I., Tyan, D., and Uulu, Y. (2010). Language Use and Language Policy in Central Asia. Central Asia Regional Data Review, 2(1), pp. 1-29.

Ardichvili, A., and Kuchinke, K. P. (2002). Leadership styles and cultural values among managers and subordinates: a comparative study of four countries of the former Soviet Union, Germany, and the US. Human Resource Development International, 5(1), pp. 99-117.

Baer, W., Cavalcanti, T., and Silva, P. (2002). Economic integration without policy coordination: the case of Mercosur. Emerging Markets Review, 3(3), pp. 269-291. 
Baldwin, R. E. (2005). Asian regionalism: promises and pitfalls. In Ahn, Baldwin, and Cheong (eds)., East Asian Economic Regionalism. New York: Springer US, pp. 157-174.

Bardhan, A. D., and Kroll, C. A. (2006). Competitiveness and an emerging sector: The Russian software industry and its global linkages. Industry and Innovation, 13(1), pp. 69-95.

Barry, F. (2003). Economic integration and convergence processes in the EU cohesion countries. JCMS: Journal of Common Market Studies, 41(5), pp. 897-921.

Begg, I., Hodson, D., and Maher, I. (2003). Economic policy coordination in the European Union. National Institute Economic Review, 183(1), pp. 66-77.

Bordachev, T., Ostrovskaya, E., and Scriba, A. (2013). The Choice and Challenge of Eurasian Integration. Rossija v global'noj politike,4(2013), http://eng.globalaffairs.ru/number/TheChoice-and-Challenge-of-Eurasian-Integration---16290.

Boschma, R. (2004). Competitiveness of regions from an evolutionary perspective. Regional studies, 38(9), pp. 1001-1014.

Bouet, A., and Laborde, D. (2010). Assessing the potential cost of a failed Doha Round. World Trade Review, 9(2), pp. 319-351.

Bristow, G. (2005). Everyone's a 'winner': problematising the discourse of regional competitiveness. Journal of Economic Geography, 5(3), pp. 285-304.

Buckley, P. J., Pass, C. L., and Prescott, K. (1988). Measures of international competitiveness: A critical survey. Journal of Marketing Management, 4(2), pp. 175-200.

Busenitz, L. W., Gomez, C., and Spencer, J. W. (2000). Country institutional profiles: Unlocking entrepreneurial phenomena. Academy of Management Journal, 43(5), pp. 994-1003.

Capannelli, G., Kawai, M. (eds.) (2014). The Political Economy of Asian Regionalism. Tokyo: Springer Japan.

Chang, H-J. (2002.) Kicking Away the Ladder: Development Strategy in Historical Perspective. London: Anthem Press.

Chen, X. (1995). The Evolution of Free Economic Zones and the Recent Development of CrossNational Growth Zones. International Journal of Urban and Regional Research, 19(4), pp. 593621.

Chikan, A. (2008). National and firm competitiveness: a general research model. Competitiveness Review, 18(1/2), pp. 20-28.

Cho, D. S. (1998). From national competitiveness to bloc and global competitiveness. Competitiveness Review, 8(1), pp. 11-23.

Cohen, A. (2013). Russia's Eurasian Union could endanger the neighbourhood and US interests. Washington DC: Heritage Foundation. 
Connolly, M. (2003). The dual nature of trade: measuring its impact on imitation and growth. Journal of Development Economics, 72(1), pp. 31-55.

Corden, W. M. (1972). Economies of scale and customs union theory. The Journal of Political Economy, 80(3), pp. 465-475.

Cordonnier, C. (2005). Russia: natural resource rent and competitiveness. Moscow: RussianEuropean Centre for Economic Policy (RECEP) Working Paper.

Dee, P. (2007). East Asian economic integration and its impact on future growth. The World Economy, 30(3), pp. 405-423.

Delmar, F., and Davidson, P. (2000). Where do they come from? Prevalence and Characteristics of nascent entrepreneurs. Entrepreneurship \& Regional Development, 12(1-4), pp. 1-23.

Dickson, P. H., Solomon, G. T., and Weaver, K. M. (2008). Entrepreneurial selection and success: does education matter?. Journal of Small Business and Enterprise Development, 15(2), pp. 239258.

Donor Committee for Enterprise Development (DCED) (2008). Supporting Business Environment Reforms: Practical Guidance For Development Agencies. London: DCED. http://rru.worldbank.org/documents/DonorGuidance.pdf.

Dowling, M. and Wignaraja, G. (2006). Central Asia after Fifteen Years of Transition: Growth, Regional Cooperation, and Policy Choices. Asia-Pacific Development Journal, 13(2), pp. 113-144.

Dragneva, R., and Wolczuk, K. (2012). Russia, the Eurasian Customs Union and the EU: Cooperation, stagnation or rivalry? Chatham House Briefing Paper No. REP BP2012/1.

Dunn, M. H. (1994). Do nations compete economically? Intereconomics, 29(6), pp. 303-308.

Duren, E. V., Martin, L., Westgren, R., Bredahl, M. E., Abbott, P. C., and Reed, M. R. (1994). A framework for assessing national competitiveness and the role of private strategy and public policy. In Bredahl, Abbott, and Reed (eds.), Competitiveness in international food markets. New York: Westview Press, pp. 37-59.

Eichengreen, B., Wyplosz, C., Bean, C., \& Gerlach, S. (1998). The Stability Pact: more than a minor nuisance? Economic Policy, 13(26), pp. 65-113.

Esty, D. C., and Porter, M. E. (2005). National environmental performance: an empirical analysis of policy results and determinants. Environment and Development Economics, 10(4), pp. 391434.

Eurobarometer (2012). Europeans and their Languages. Brussels: European Commission.

Fidrmuc, J., and Fidrmuc, J. (2014). Foreign Language and Trade: Evidence from Quantile Regressions. Paper presented at CESifo Conference on Estimation of Gravity Modes of Bilateral Trade, May 30-31. 
Florin, J., Karri, R., and Rossiter, N. (2007). Fostering entrepreneurial drive in business education: An attitudinal approach. Journal of Management Education, 31(1), pp. 17-42.

Fung, K. C. (1992). Economic integration as competitive discipline. International Economic Review, 33(4), pp. 837-847.

Furman, J. L., Porter, M. E., and Stern, S. (2002). The determinants of national innovative capacity. Research policy, 31(6), pp. 899-933.

Garrett, G. (1992). International cooperation and institutional choice: the European Community's internal market. International Organization, 46(2), pp. 533-560.

Gehrels, F. (1956). Customs union from a single-country viewpoint. The Review of Economic Studies, 24(1), pp. 61-64.

Gennaioli, N., La Porta, R., Lopez-de-Silanes, F., \& Shleifer, A. (2013). Human Capital and Regional Development. Quarterly Journal of Economics, 128(1), pp. 105-164.

Grigoriou, C. (2007). Landlockedness, infrastructure and trade: new estimates for Central Asian countries. Washington DC: World Bank.

Gros, D., and Alcidi, C. (2010). Fiscal Policy Coordination and Competitiveness Surveillance: What solutions to what problems? Centre for European Policy Studies Policy Brief No. 213, September.

Gugler, P., and Brunner, S. (2007). FDI effects on national competitiveness: A cluster approach. International Advances in Economic Research, 13(3), pp. 268-284.

Hanks, R. R. (2009). 'Multi-vector politics' and Kazakhstan's emerging role as a geo-strategic player in Central Asia. Journal of Balkan and Near Eastern Studies, 11(3), pp. 257-267.

Hanson, G. H. (2001). US-Mexico integration and regional economies: evidence from bordercity pairs. Journal of Urban Economics, 50(2), pp. 259-287.

Harders, C., and Legrenzi, M. (2008). Beyond regionalism? Regional cooperation, regionalism and regionalization in the Middle East. London: Ashgate Publishing.

Hartwell, C. A. (2014). Capital Controls and the Determinants of Entrepreneurship. Czech Journal of Economics \& Finance, 64(6), pp. 434-456.

(2013) A Eurasian (or a Soviet) Union? Consequences of further economic integration in the Commonwealth of Independent States. Business Horizons, 56(4), pp. 411-420.

Heal, A., and Mladenovic, T. (2014). Kazakhstan's membership of the Eurasian Customs Union: Implications for trade and WTO accession. Asia-Pacific Research and Training Network on Trade Policy Brief No. 39, June. 
Hermann, C. (2007). Neoliberalism in the European Union. Studies in Political Economy, 79, pp. 61-90.

Herzog, B. (2006). Coordination of fiscal and monetary policy in CIS-countries: A theory of optimum fiscal area? Research in International Business and Finance, 20(2), pp. 256-274.

Heslop, H.B. (2003). The Caspian states of the former Soviet Union: economic performance since 1998. In Cummings (ed.), Oil, Transition, and Security in Central Asia. New York: Routledge, pp. 175-191.

Heyneman, S. P., Anderson, K. H., and Nuraliyeva, N. (2008). The cost of corruption in higher education. Comparative Education Review, 52(1), pp. 1-25.

Holden, N., and Vaiman, V. (2013). Talent management in Russia: not so much war for talent as wariness of talent. Critical Perspectives on International Business, 9(1/2), pp. 129-146.

Holden, N., Kuznetsov, A., and Whitelock, J. (2008). Russia's struggle with the language of marketing in the communist and post-communist eras. Business History, 50(4), pp. 474-488.

Hvidt, M. (2009). The Dubai model: An outline of key development-process elements in Dubai. International Journal of Middle East Studies, 41(3), pp. 397-418.

Johnson, C. M. (2009). Cross-border regions and territorial restructuring in central Europe room for more transboundary space. European Urban and Regional Studies, 16(2), pp. 177-191.

Jovanovic, M. (2006). International economic integration: limits and prospects. New York: Routledge.

Kaiser, R., and Prange, H. (2005). Missing the Lisbon target? Multi-level innovation and EU policy coordination. Journal of Public Policy, 25(2), pp. 241-263.

Kalyuzhnova, Y., and Nygaard, C. A. (2011). Special vehicles of state intervention in Russia and Kazakhstan. Comparative Economic Studies, 53(1), pp. 57-77.

Kao, C., Wu, W. Y., Hsieh, W. J., Wang, T. Y., Lin, C., and Chen, L. H. (2008). Measuring the national competitiveness of Southeast Asian countries. European Journal of Operational Research, 187(2), pp. 613-628.

Ketels, C. H. (2006). Michael Porter's competitiveness framework-recent learnings and new research priorities. Journal of Industry, Competition and Trade, 6(2), pp. 115-136.

Knobel, A., and Pereboyev, V. (2013). Eurasian Partnership: Potential Instruments for External Relations of the Eurasian Economic Union. In Vinokurov (ed.), Eurasian Integration Yearbook 2013. Almaty: Eurasian Development Bank, pp. 28-49.

Krotov, I. (2011). Customs Union between the Republic of Belarus, the Republic of Kazakhstan and the Russian Federation within the framework of the Eurasian Economic Community. World Customs Journal, 5(2), pp. 133-137. 
Krugman, P. (1994). Competitiveness: a dangerous obsession. Foreign Affairs 73(2), pp. 28-44.

Krugman, P., and Venables, A. J. (1990). Integration and the competitiveness of peripheral industry. In Bliss and De Macedo (eds.), Unity with diversity in the European Community: the Community's Southern Frontier. Cambridge: Cambridge University Press, pp. 56-77.

Kurmanalieva, E. (2008). Empirical analysis of Kyrgyz trade patterns. Eurasian Journal of Business and Economics, 1(1), pp. 83-97.

Lall, S. (2001). Competitiveness indices and developing countries: an economic evaluation of the global competitiveness report. World Development, 29(9), pp. 1501-1525.

Landesmann, M.A., and Stehrer, R. (2006). Modelling International Economic Integration: Patterns of Catching-up and Foreign Direct Investment. Economia politica (3/2006), pp. 335362.

Laruelle, M., and Peyrouse, S. (2009). Cross-border minorities as cultural and economic mediators between China and Central Asia. China and Eurasia Forum Quarterly, 7(1), pp. 93119).

Lazenby, J.A.A., and Machaba, R.P. (2011). A Descriptive Analysis of Gauteng Entrepreneurs With Respect to the Old Debate of Whether Entrepreneurship is an Inborn Quality or can be Learnt. International Journal of Business and Social Science, 2(21), pp. 72-80.

Lee, S. Y., Florida, R., and Acs, Z. (2004). Creativity and entrepreneurship: a regional analysis of new firm formation. Regional Studies, 38(8), pp. 879-891.

Lohmann, G., Albers, S., Koch, B., and Pavlovich, K. (2009). From hub to tourist destination-An explorative study of Singapore and Dubai's aviation-based transformation. Journal of Air Transport Management, 15(5), pp. 205-211.

Malamud, A. (2005). Mercosur turns 15: Between rising rhetoric and declining achievement. Cambridge Review of International Affairs, 18(3), pp. 421-436.

Man, T. W., Lau, T., and Chan, K. F. (2002). The competitiveness of small and medium enterprises: a conceptualization with focus on entrepreneurial competencies. Journal of Business Venturing, 17(2), pp. 123-142.

Mansfield, E. D., and Milner, H. V. (1999). The new wave of regionalism. International Organization, 53(3), pp. 589-627.

Marques, H., and Metcalf, H. (2005). What determines sectoral trade in the enlarged EU? Review of Development Economics, 9(2), pp. 197-231.

Maskell, P., and Malmberg, A. (1999a). Localised learning and industrial competitiveness. Cambridge Journal of Economics, 23(2), pp. 167-185.

(1999b). The Competitiveness of Firms and Regions 'Ubiquitification' and the Importance of Localized Learning. European Urban and Regional Studies, 6(1), pp. 9-25. 
Malmberg, A., Sölvell, Ö., and Zander, I. (1996). Spatial clustering, local accumulation of knowledge and firm competitiveness. Geografiska Annaler. Series B. Human Geography, 78(2), pp. 85-97.

Maskus, K. (2012). Observations on Innovation and Technology Use in the BRICS. Law and Business Review of the Americas, 18(4), pp. 537-552.

McClory, J. (2012). The New Persuaders III: A 2012 Global Ranking of Soft Power. London: Institute for Government.

Mesquita, L. F., Lazzarini, S. G., and Cronin, P. (2007). Determinants of firm competitiveness in Latin American emerging economies: Evidence from Brazil's auto-parts industry. International Journal of Operations \& Production Management, 27(5), pp. 501-523.

Mkrtchyan, A., and Gnutzmann, H. (2013). Mutual Protectionism? An Assessment of the Eurasian Customs Union. Florence: European University Institute.

Miles, R. E., and Snow, C. C. (1994). Fit, failure and the hall of fame: How companies succeed or fail. New York: Free Press.

Milner, H. V. (1999). The political economy of international trade. Annual Review of Political Science, 2(1), pp. 91-114.

Motta, M., and Norman, G. (1996). Does economic integration cause foreign direct investment?. International Economic Review, 37(4), pp. 757-783.

Narula, R., and Wakelin, K. (1998). Technological competitiveness, trade and foreign direct investment. Structural change and economic dynamics, 9(3), pp. 373-387.

Nye, J. S. (2008). Public diplomacy and soft power. The Annals of the American Academy of Political and Social Science, 616(1), pp. 94-109.

Ōmae, K. (1995). The end of the nation state: The rise of regional economies. New York: Simon and Schuster.

Oomes, N., and Kalcheva, K. (2007). Diagnosing Dutch disease: Does Russia have the symptoms? Bank of Finland Institute for Economies in Transition (BOFIT) Working Paper No. $7 / 2007$.

Pacione, M. (2005). Dubai. Cities, 22(3), pp. 255-265.

Panagariya, A. (2011). A re-examination of the infant industry argument for protection. The Journal of Applied Economic Research, 5(1), pp. 7-30.

Peyrouse, S. (2012). The Kazakh Neopatrimonial Regime: Balancing Uncertainties among the "Family," Oligarchs and Technocrats. Demokratizatsiya: The Journal of Post-Soviet Democratization, 20(4), pp. 345-370. 
Pfeffer, J., and Fong, C. T. (2004). The Business School 'Business': Some Lessons from the US Experience. Journal of Management Studies, 41(8), pp. 1501-1520.

Pilipenko, I. V. (2013). The Sochi 2014 Winter Olympics-the cost-benefit analysis and ways to improve the project efficiency. Tartu: Pan-European Institute.

Porter, M. E. (1990). The Competitive Advantage of Nations. Harvard Business Review, MarchApril, pp. 73-91.

Raballand, G., and Andrésy, A. (2007). Why should trade between Central Asia and China continue to expand? Asia Europe Journal, 5(2), pp. 235-252.

Raballand, G., Kunth, A., and Auty, R. (2005). Central Asia's transport cost burden and its impact on trade. Economic Systems, 29(1), pp. 6-31.

Rauch, J. E. (1999). Networks versus markets in international trade. Journal of international Economics, 48(1), pp. 7-35.

(2001). Business and social networks in international trade. Journal of Economic Literature, 39(4), pp. 1177-1203.

Raymond, M. A., McNabb, D. E., and Matthaei, C. F. (1993). Preparing graduates for the workforce: The role of business education. Journal of Education for Business, 68(4), pp. 202206.

Sachs, J. D., and Warner, A. M. (2001). The curse of natural resources. European Economic Review, 45(4), pp. 827-838.

Shadikhodjaev, S. (2009). Trade Integration in the CIS Region: A Thorny Path Towards a Customs Union. Journal of International Economic Law, 12(3), pp. 555-578.

Shagdar, B. (2006). Human capital in Central Asia: trends and challenges in education. Central Asian Survey, 25(4), pp. 515-532.

Singla, S. K. (2014). Development Experience of Central Asian Countries since their Independence. Asian Journal of Business and Economics, 4(4.2), pp. 1-21.

Skolkovo Institute for Emerging Market Studies (SIEMS) (2012). SIEMS Emerging Market Soft Power Index. SIEMS Emerging Market Policy Brief No. 12-01, February.

Smith, H. (2002). Innovation Systems in Transition: Preconditions for Success: The Electronics Sector in the Former Soviet Union. Bulletin of Science, Technology \& Society, 22(6), pp. 496-512.

Snieška, V., and Drakšaitè, A. (2007). The role of knowledge process outsourcing in creating national competitiveness in global economy. Engineering Economics, 3(53), pp. 35-41.

Solesvik, M. Z. (2013). Entrepreneurial motivations and intentions: investigating the role of education major. Education+Training, 55(3), pp. 253-271. 
Strasky, J., Pashinova, T., Lanzeni, M. L., Ag, D. B., Hoffmann, R., and Speyer, B. (2012). What drives FDI to Russian regions? Deutsche Bank Research Emerging Markets Research Briefing, November 28.

Tarr, D. G. (2012). The Eurasian Customs Union among Russia, Belarus and Kazakhstan: Can It Succeed Where Its Predecessor Failed? Available at SSRN: http://ssrn.com/abstract=2185517.

Thompson, E. R. (2004). National competitiveness: a question of cost conditions or institutional circumstances? British Journal of Management, 15(3), pp. 197-218.

Topalova, P., and Khandelwal, A. (2011). Trade liberalization and firm productivity: The case of india. Review of Economics and Statistics, 93(3), pp. 995-1009.

Van der Ploeg, F. (2011). Natural resources: Curse or blessing? Journal of Economic Literature, 49(2), pp. 366-420.

Varblane, U., and Mets, T. (2010). Entrepreneurship education in the higher education institutions (HEls) of post-communist European countries. Journal of Enterprising Communities: People and Places in the Global Economy, 4(3), pp. 204-219.

Vinokurov, E. (2012). The Customs Union and the Single Economic Space: Towards the Eurasian Economic Union. In Vinokurov (ed.), EDB Eurasian Integration Yearbook 2012. Almaty: Eurasian Development Bank.

(2013). Pragmatic Integration. In Vinokurov (ed.), EDB Eurasian Integration Yearbook 2013. Almaty: Eurasian Development Bank.

Vinokurov, E., and Libman, A. (2014). Do economic crises impede or advance regional economic integration in the post-Soviet space? Post-Communist Economies, 26(3), pp. 341-358.

Vymyatnina, Y., and Antonova, D. (2014). Creating a Eurasian Union: Economic Integration of the Former Soviet Republics. Basingstoke: Palgrave Macmillan.

Waheeduzzaman, A. N. M., and Ryans Jr, J. K. (1996). Definition, perspectives, and understanding of international competitiveness: a quest for a common ground. Competitiveness Review, 6(2), pp. 7-26.

Walz, U. (1997). Dynamic effects of economic integration: A survey. Open Economies Review, 8(3), pp. 309-326.

Wan, D., Ong, C. H., and Lee, F. (2005). Determinants of firm innovation in Singapore. Technovation, 25(3), pp. 261-268.

Wisniewska, I. (2012). The Customs Union of Belarus, Kazakhstan and Russia: a way to strengthen Moscow's position in the region. Instituto per gli Studi de Politica Internazionale (ISPI) Analysis, No. 146. 
World Economic Forum (2014). Russia's Regions Drivers of Growth: 4x4. Geneva: World Economic Forum.

Yi, S. S. (1996). Endogenous formation of customs unions under imperfect competition: open regionalism is good. Journal of International Economics, 41(1), pp. 153-177. 